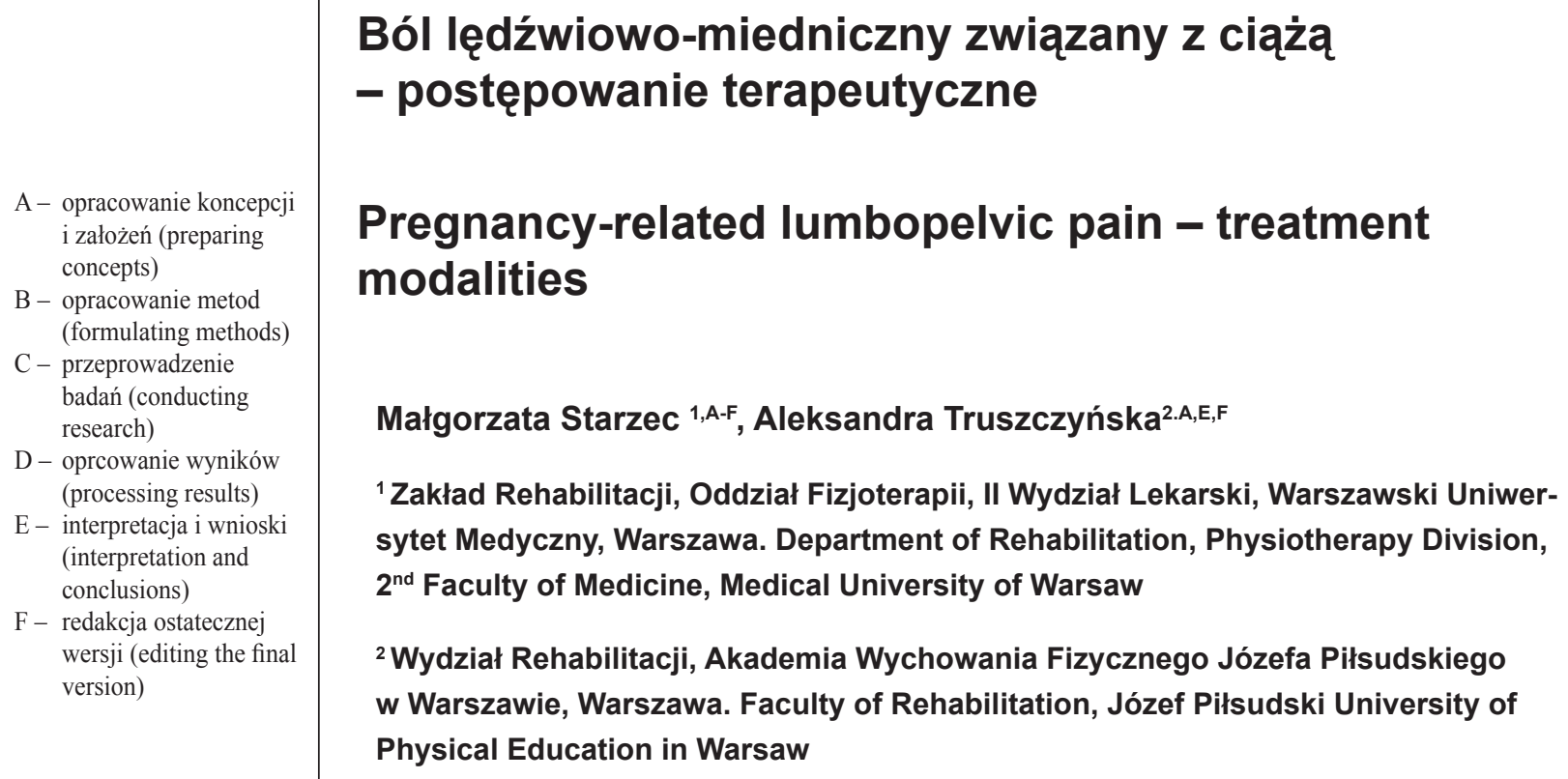

A - opracowanie koncepcji i założeń (preparing concepts)

B - opracowanie metod (formulating methods)

$\mathrm{C}$ - przeprowadzenie badań (conducting research)

D - oprcowanie wyników (processing results)

E - interpretacja i wnioski (interpretation and conclusions)

F - redakcja ostatecznej wersji (editing the final version)

\section{Pregnancy-related lumbopelvic pain - treatment modalities}

\author{
Małgorzata Starzec ${ }^{1, A-F}$, Aleksandra Truszczyńska ${ }^{2 . A, E, F}$
}

${ }^{1}$ Zakład Rehabilitacji, Oddział Fizjoterapii, II Wydział Lekarski, Warszawski Uniwersytet Medyczny, Warszawa. Department of Rehabilitation, Physiotherapy Division, $2^{\text {nd }}$ Faculty of Medicine, Medical University of Warsaw

${ }^{2}$ Wydział Rehabilitacji, Akademia Wychowania Fizycznego Józefa Piłsudskiego w Warszawie, Warszawa. Faculty of Rehabilitation, Józef Piłsudski University of Physical Education in Warsaw

\section{Słowa kluczowe:}

Key words:

\section{Streszczenie}

Wstęp: Ból lędźwiowo-miedniczny jest częstą przypadłością okresu ciąży, która nierzadko ogranicza codzienną aktywność ciężarnej. Dolegliwości te wymagają odpowiedniego, zindywidualizowanego postępowania, gdyż zlekceważone, mogą przekształcić się w długotrwałą dysfunkcję.

Celem pracy było przedstawienie najnowszych doniesień na temat możliwych strategii postępowania z bólem lędźwiowo-miednicznym.

Podsumowanie: Dzisiejsza nauka dostarcza nam wiele efektywnych narzędzi, które pozwalają na redukcję bólu i ograniczeń funkcjonalnych bez szkody dla ciężarnej i dziecka. Brak jest jednej, najefektywniejszej strategii leczenia bólu lędźwiowo-miednicznego. Najlepsze wyniki przynosi kombinacja metod, których skuteczność została potwierdzona badaniami.

ból odcinka lędźwiowego, obręcz miedniczna, ciąża, leczenie

\section{Abstract}

Introduction: Pregnancy-related lumbopelvic pain is a common complaint which often limits everyday activity of a pregnant woman. Accurate and individualized treatment is needed as, if ignored, pain can become a long term condition.

The aim of this article is to present the current state of knowledge about possible treatment modalities for pregnancy-related lumbopelvic pain.

Summary: Current knowledge gives us a variety of effective tools which help reduce pain and functional limitations with no harm to a mother and foetus. There is no single and most effective treatment strategy. A combination of evidence-based methods produces the best treatment outcomes.

lumbar pain, pelvic girdle, pregnancy, treatment 
Wstęp

Ból lędźwiowo-miedniczny (z ang. lumbopelvic pain, LPP) związany z ciążą dzieli się na ból odcinka lędźwiowego kręgosłupa ( $\mathrm{z}$ ang. lumbar pain, LP), ból obręczy miednicznej ( $\mathrm{z}$ ang. pelvic girdle pain, PGP) oraz ból mieszany, związany z występowaniem obu jednocześnie [1].

Dolegliwości te dotyczą wielu kobiet w okresie ciąży, negatywnie wpływając na życie zawodowe, codzienną aktywność oraz sen [2]. Obraz kliniczny jest zróżnicowany, nie tylko osobniczo, ale też w czasie [3].

Wśród pracowników służby zdrowia często brak jest wiedzy na temat skutecznych strategii postępowania z bólem w okresie ciąży. Przekonanie, że LPP jest dolegliwością tymczasową i samoograniczającą się sprawia, że niewiele kobiet otrzymuje odpowiednią pomoc [4]. Jednakże, u $25 \%$ z nich dolegliwości te zostają również po porodzie [3] i mogą negatywnie wpływać na jakość życia przez miesiące, a nawet lata [5]. Złożoność tych dolegliwości oraz socjoekonomiczne konsekwencje przewlekłych zespołów bólowych wymagają odpowiedniego leczenia, podjętego możliwie jak najwcześniej.

Celem artykułu było przedstawienie najnowszych doniesień na temat możliwych strategii postępowania z LPP.

\section{Farmakoterapia}

Jedynym bezpiecznym środkiem przeciwbólowym dla kobiet w ciąży jest paracetamol. Jednak jego efektywność w zmniejszaniu LPP jest niska $[4,6,7]$. Większą skuteczność w postępowaniu przeciwbólowym wykazują niesteroidowe leki przeciwzapalne, ale zalecane są tylko do 30 tygodnia ciąży. W piśmiennictwie pojawiają się również informacje o małych dawkach leków opioidowych jako szczególnie pomocnych w przypadku bólów nocnych i problemów ze snem. Liczba dowodów naukowych na temat ich zastosowania w leczeniu LPP jest jednak niewielka, szczególnie u kobiet w ciąży. Badania na zwierzętach wykazały, że ich stosowanie może, ale nie musi wiązać się z ryzykiem dla płodu [4].

Ból należy różnicować na wywoływany w stawie (obwodowo) i w mózgu (centralna sensytyzacja) [8]. Właściwym postępowaniem jest niedopuszczenie do sytuacji, w której receptorowy ból obwodowy staje się bólem sterowanym centralnie,

\section{Introduction}

Pregnancy-related lumbopelvic pain (LPP) can be categorized into lumbar pain (LP), pelvic girdle pain (PGP) or mixed pain, i.e. these two types of pain felt simultaneously [1].

These ailments affect many pregnant women, thus exerting a negative influence on their professional life, everyday activities and sleep [2]. The clinical evidence may be diversified - it may be different for different patients and it may change for the same patient with time [3].

Health care professionals often lack the knowledge on how to successfully treat pain in pregnant women. The conviction that LPP is a temporary and self-eliminating problem results in the fact that few women receive appropriate help [4]. Still, 25\% of them suffer from post-birth LPP [3]. LPP may negatively affect their quality of life for months or even years [5]. The complexity of the ailment as well as socio-economic consequences of chronic pain require adequate treatment introduced as early as possible.

The aim of the article is to present the latest findings on the possible LPP treatment strategies.

\section{Pharmacotherapy}

Paracetamol is the only painkiller safe for pregnant women. Still, its effect in LPP relief is low $[4,6,7]$. Nonsteroidal anti-inflammatory drugs are more efficient in pain relief, yet they are not recommended after 30 weeks of pregnancy. The literature mentions small doses of opioids particularly helpful in night pain and sleep disorders. However, scientific evidence on their application to treat LPP is limited, especially in pregnant women. Tests on animals have shown that they may, though do not have to, result in risk for the foetus [4].

Pain may be categorized into pain triggered in the joint (peripheral pain) and pain triggered in the brain (central sensitization) [8]. The recommended treatment strategy is not to allow receptor-generated peripheral pain to become generated centrally, thus leading to chronic pain. In such cases, it seems advisable to introduce small doses of anti-depressant drugs [9].

\section{Physiotherapy}

Research has shown that numerous forms of physiotherapy can benefit LPP therapy. Even though we 
prowadząc do bólów przewlekłych. W takim przypadku zasadnym jest wdrożenie leczenia małymi dawkami leków antydepresyjnych [9].

\section{Fizjoterapia}

Badania pokazują, że za pomocą różnych form fizjoterapii można uzyskać pozytywne efekty w terapii LPP. Choć brak jest jednoznacznych, silnych dowodów na skuteczność którejkolwiek z metod stosowanych przez fizjoterapeutów, to te formy leczenia bezsprzecznie prowadzą do lepszych rezultatów w redukcji bólu, niesprawności i liczby zwolnień lekarskich niż standardowa opieka położnicza [10]. Ze względu na kompleksowość schorzenia, jakim jest LPP, uzasadnionym wydaje się być stosowanie wielodyscyplinarnego podejścia, łączącego w sobie kombinację różnych procedur takich jak terapia manualna, metoda McKenziego, ćwiczenia i edukacja pacjentki.

Edukacja pacjentki. W przypadku LPP obejmuje takie zagadnienia jak: podstawy anatomii, informacja o schorzeniu, czynniki ryzyka, ergonomia, prawidłowa postawa, techniki radzenia sobie z bólem, techniki relaksacyjne $[6,11,12,13]$. Kobiety ciężarne, u których występuje LP powinny unikać nadmiernego zmęczenia oraz ruchów rotacyjnych podczas dźwigania. Zaleca się utrzymywanie prawidłowej postawy i częsty odpoczynek podczas aktywności [11]. Dodatkowo, kobiety z PGP powinny unikać podskoków, nierównomiernego obciążania kończyn dolnych (np. podczas ubierania spodni), nadmiernego odwiedzenia $w$ stawach biodrowych oraz aktywności w końcowych zakresach ruchu [14]. Podczas obracania się w łóżku, kolana powinny być zgięte i złączone [15].

Kinezyterapia i ćwiczenia. Kobiety, które regularnie ćwiczą lepiej znoszą dolegliwości związane z LPP [16]. Ćwiczenia (ang. exercises therapy) mają pozytywny efekt na zmniejszenie bólu, poprawę sprawności i/lub aktywność zawodową u pacjentek z LP. Efekt ten jest mniejszy u kobiet cierpiących na PGP. Dla tych pacjentek autorzy europejskich wytycznych zalecają zindywidualizowany program ćwiczeń zorientowany na odpowiednie zachowania podczas aktywności dnia codziennego oraz unikanie czynności wywołujących ból [6]. Według tych wytycznych istnieje wystarczająca liczba dowodów naukowych potwierdzających skuteczność ćwiczeń stabilizujących po urodzeniu dziecka. Opracowany, specjalistyczny program tych ćwiczeń zmniejsza lack strong and unambiguous evidence for the effectiveness of any particular method of physiotherapy, it is indisputable that physiotherapy leads to better results in pain relief, disability control and limiting the number of sick leaves than the standard obstetric medical care [10]. As LPP is a complex disorder, a multidisciplinary approach is advised - a combination of procedures such as manual therapy, McKenzie method, exercise and patient education.

Patient education. In the case of LPP, patient education should include the following issues: basic information on anatomy, information on the disorder, risk factors, ergonomics, healthy posture, pain relieving techniques, relaxation techniques $[6,11,12,13]$. Pregnant women suffering from LP should avoid excessive exhaustion or rotating movements when lifting objects. They should maintain healthy posture and make frequent pauses in their activities [11]. In addition, women who suffer from PGP should refrain from jumping, uneven loading of lower limbs (e.g. when putting on a pair of trousers), excessive abduction in the hip joint or activities requiring end range movements [14]. When turning in bed, the patient should keep her knees bent and joined together [15].

Kinesiotherapy and exercise. Women who exercise regularly find it easier to bear LPP related ailments. Exercise therapy brings positive effect on pain relief, improves fitness and/or professional activity in patients with LP. The effect is weaker in patients who suffer from PGP. For PGP patients, authors of European guidelines recommend an individualized exercise programme focused on practising healthy behaviour in everyday activities as well as refraining from activities that result in pain [6]. According to these recommendations, there is adequate scientific evidence to support the effectiveness of stabilizing exercises done after birth. A specially designed exercise programme reduces pain intensity and disability and improves quality of life better than conventional physiotherapy (massages, relaxation, joint mobilization, electrotherapy, warm compresses, mobilizing and strengthening exercises) without stabilizing exercises. The beneficial effect can be still visible as long as two years later $[17,18]$. Some authors reported a positive effect of stabilizing exercises as early as in the pregnancy period $[16,19,20]$. There is limited evidence, however, on the specificity of the training and exercises that should be done, since only a few studies investigated the impact of a particular type of movement activity [21]. Water gymnastics is a similar case. The 
intensywność bólu i niesprawność oraz poprawia jakość życia w porównaniu do konwencjonalnej fizjoterapii (masaż, relaksacja, mobilizacja stawów, manipulacja, elektroterapia, ciepłe okłady, ćwiczenia mobilizujące i wzmacniające) bez ćwiczeń stabilizacyjnych, a ich efekt jest wciąż widoczny 2 lata później $[17,18]$. Niektórzy autorzy donieśli o pozytywnym wpływie ćwiczeń stabilizujących już w okresie ciąży $[16,19,20]$. Istnieje jednak mała liczba dowodów na temat specyfiki treningu i ćwiczeń, jakie powinny być zastosowane, ponieważ istnieje tylko kilka prac badających wpływ konkretnego typu zadania ruchowego [21]. Podobnie sytuacja przedstawia się odnośnie ćwiczeń w wodzie. W dostępnych doniesieniach [22] przyniosły one znaczącą redukcję intensywności odczuwanego bólu oraz mniejszy odsetek urlopów zdrowotnych wśród kobiet z LP jednakże nie zaobserwowano podobnych efektów w grupie z PGP. Ze względu na małą ilość randomizowanych badań kontrolowanych siła tych dowodów nie jest wystarczająca, aby móc bezsprzecznie stwierdzić o skuteczności tego rodzaju interwencji [21]. Leczenie ruchem przynosi lepsze efekty niż standardowa opieka położnicza (farmakoterapia, informacja dla pacjenta o schorzeniu, zalecenie ćwiczeń aerobowych, ciepłych okładów i odpowiedniej ilości odpoczynku) [23]. Jest ono bezpieczne zarówno dla matki jak i dziecka. Zaleca się aktywność fizyczną o charakterze aerobowym i wzmacniającym, o średniej intensywności, minimum 3 razy w tygodniu po 30 minut bądź więcej [24]. Stosując tą terapię warto uzupełnić ją o indywidualnie dobrane, wykonywane 1-2 razy w tygodniu, specjalistyczne treningi mające na celu poprawę równowagi, wzmocnienie mięśni grzbietu, obręczy miedniczej i dna miednicy, kokontrakcję mięśnia poprzecznego brzucha i mięśni dna miednicy z innymi grupami mięśniowymi [10].

Terapia manualna. Dostępne badania dotyczące efektów terapii manualnej w postępowaniu z LPP są nieliczne. Brak jest randomizowanych badań kontrolowanych badających efekt mobilizacji stawów kręgosłupa i stawów krzyżowo-biodrowych [21]. Choć w badaniach George i wsp. [23] terapia manualna wydaje się przyczyniać do uzyskanych efektów, to ze względu na złożony charakter zastosowanej interwencji, nie można wysnuć żadnych wniosków odnośnie jej wyizolowanego działania. Jednakże istnieje kilka prac, które mogą posłużyć, jako punkt odniesienia dla przyszłych badań oraz wskazówka dla fizjoterapeutów posługujących się metodami available studies [22] reported a significant reduction in pain intensity and a reduced number of sick leaves among women suffering from LP, yet these effects were not observed in women with PGP. As the number of randomized controlled tests was limited, the evidence is not strong enough to explicitly prove the effect of such treatment [21]. Exercise therapy has better effects than standard obstetrics (pharmacotherapy, informing a patient on the disorder, recommending aerobics, warm compresses and an appropriate amount of rest) [23]. It is safer for both the mother and the foetus. The recommended activity is aerobics and strengthening exercises of medium intensity (a minimum of 30 minutes three times a week) [24]. It is advisable to complement this therapy with individually designed and specialized training conducted once or twice a week aimed at improving balance as well as strengthening muscles of the back, pelvic girdle and pelvic floor and co-contracting the transverse abdominal muscle and pelvic floor muscles with other muscle groups [10].

Manual therapy. There are few studies on the effects of manual therapy in LPP treatment. There are no randomized control studies on the effect of mobilization of spinal joints and sacroiliac joints [21]. Although in the study by George et al. [23] manual therapy seemed to have contributed to the achieved effects, the complex character of the treatment used prevents us from reaching any conclusions on manual therapy effects in isolation. Still, there are several studies which may serve as a starting point for future research and as instructions for physiotherapists who use manual therapy with pregnant patients with LPP. Peterson et al. [25] managed to achieve an improvement in the functioning and reduction of pain when using manipulation techniques of High Velocity Low Amplitude (HVLA) on hypomobile spinal joints. There are also some positive reports on the passive and active effects of lumbar spine and sacroiliac joints mobilization [21]. Murphy et al. [26] observed positive effects of manual therapy applied within diagnosis-based clinical assessment schedule.

Physical Agents. Transcutaneous electrical nerve stimulation (TENS) can be used in pregnant women, as there is no risk of side effects provided that contraindications are excluded and that acupuncture points that might induce premature labour are avoided [27]. In their study on TENS treatment in third trimester pregnant women with LP, Keskin et al [28] 
terapii manualnej oraz pracujących $\mathrm{z}$ ciężarnymi pacjentkami z LPP. Peterson i wsp. [25] uzyskali poprawę funkcji i zmniejszenie bólu stosując techniki manipulacyjne o dużej szybkości i małej amplitudzie (ang. HVLA: High Velocity Low Amplitude) na hypomobilne stawy kręgosłupa. Istnieją również pozytywne doniesienia o efektach pasywnych i aktywnych mobilizacji kręgosłupa lędźwiowego oraz stawów krzyżowo-biodrowych [21]. Murphy i wsp. [26] w swoich badaniach obserwacyjnych donieśli o pozytywnych wynikach terapii manualnej zastosowanej na podstawie protokołu oceny klinicznej pacjenta opartego na diagnozie (ang. diagnosis-based clinical assesment schedule).

Fizykoterapia. Przezskórna elektryczna stymulacja nerwów (TENS) może być stosowana w ciąży, bez obawy o wywołanie skutków ubocznych, pod warunkiem wykluczenia przeciwwskazań i unikania punktów akupunkturowych mogących wywołać przedwczesny poród [27]. W badaniach Keskin i wsp. [28] zastosowanie terapii TENS u kobiet z LP, $\mathrm{w}$ trzecim trymestrze, przyniosło znaczącą redukcję intensywności bólu i poprawę funkcji. Efekt ten był większy niż w przypadku grupy z domowym zestawem ćwiczeń i grupy otrzymującej farmakoterapię. Jednakże dowody naukowe na skuteczność TENS, jako jedynej formy terapii są niewystarczające. Biorąc jednak pod uwagę ograniczone możliwości redukcji bólu w ciąży, podjęcie próby leczenia za pomocą TENS jest jak najbardziej rekomendowane. Jest to niekosztowna, łatwo dostępna metoda, która niesie za sobą mniejsze ryzyko niż farmakoterapia i akupunktura. Zabiegi TENS powinny być stosowane, jako leczenie „drugiej linii” w przypadku LP i PGP, po wcześniejszej edukacji pacjentki i zastosowaniu kinezyterapii $\mathrm{w}$ formie indywidualnie dobranych ćwiczeń. [27].

Zaopatrzenie ortopedyczne. Głównie $\mathrm{z}$ powodu małej liczby badań sprawdzających skuteczność działania zaopatrzenia ortopedycznego, jako osobnego postępowania, nie znaleziono wystarczających dowodów, by rekomendować jego stosowanie [10]. Jest to zgodne $\mathrm{z}$ informacjami zawartymi w europejskich wytycznych odnośnie postępowania z PGP, niemniej jednak zalecają one ich stosowanie w przypadku, gdy przynoszą ulgę w dolegliwościach, z zaznaczeniem, że powinny być używane przez krótki okres czasu [6]. Pas stabilizujący miednicę może okazać się pomocny w przypadku dysfunkcji mechanizmu ryglowania siłowego (niewystarczające ryglowanie siłowe) $[6,8,13,29]$. W badaniach Kordi i found that the TENS treatment resulted in a considerable reduction of pain intensity and in a substantial increase in function. The effect was larger than in the case of a group who did a set of exercises at home and a group who received pharmacotherapy. Still, scientific evidence on TENS effectiveness as a single therapeutic method is insufficient. However, as the number of methods of pain relief in pregnant women is limited, an attempt to use TENS is fully recommended. It is a low-cost, easily accessible method, with lower risk levels than pharmacotherapy and acupuncture. TENS treatment should be used as "second line" in the case of LP and PGP, following patient education and kinesiotherapy in the form of individually designed exercise plan [27].

Orthosis. It is mainly because of a limited number of studies on the effect of orthosis as a single treatment method that not enough evidence has been found for it to be recommended [10]. This is in line with the European guidelines on PGP treatment. European guidelines suggest using orthosis when it relieves pain although it is pointed out that it should be used over a limited period of time [6]. The pelvic belt may prove helpful in the case of insufficient force closure mechanism $[6,8,13,29]$. In their study, Kordi et al [30] found that the pelvic belts they used significantly decreased pain intensity and disability in comparison to exercise and to general educational information. It seems that using pelvic belts is most advisable in the case of symphysis pain. There are two versions of pelvic belts available, the "soft" one and the "stiff" one, of which the former seems to be more effective and more comfortable for the patient [31]. The belt worn in the "high" position (just below the upper spinae iliaca) improves the stabilization of the sacroiliac joints [14], while the "low" position (worn just above the symphysis) is used in the case of symphysis dysfunctions [31]. It is recommended that the patient should decide whether to use crutches or a pelvic belt. If she reports diminishing PGP pain, their use is justified.

Prevention. Although it is difficult to prevent LPP, appropriate patient information and care about physical fitness (e.g. proper physical activity, body posture, ergonomics) may reduce pain and/or make it less traumatizing [13]. Pelvic floor muscle exercise, as an element of specially designed 12-week training, may be helpful in preventing LPP in advanced pregnancy periods and result in the pregnant patient functioning better [33]. It has been proved that there is a correlation between muscle dysfunction and 
wsp. [30] zastosowane pasy do stabilizacji miednicy znacząco zmniejszyły intensywność bólu i niesprawność w porównaniu do ćwiczeń i w porównaniu do ogólnej informacji edukacyjnej. Najbardziej uzasadnione wydaje się być użycie pasa w przypadku bólu spojenia łonowego. Spośród dostępnych na rynku wersji „miękkiej” i „sztywnej” ta pierwsza wydaje się być efektywniejsza i wygodniejsza [31]. Pas założony w pozycji „wysokiej” (zaraz poniżej kolców biodrowych przednich górnych) poprawia stabilizację stawów krzyżowo- biodrowych [14], natomiast pozycja „niska” (zaraz nad spojeniem łonowym) stosowana jest dla dysfunkcji spojenia [31]. Decyzję o zastosowaniu kul bądź pasa rekomenduje się zostawiać pacjentce - jeżeli odczuwa ona zmniejszenie dolegliwości związanych z PGP, stosowanie ich jest uzasadnione [32].

Profilaktyka. Choć trudno zapobiec LPP, to odpowiednia informacja dla pacjentki oraz dbałość o dobrostan fizyczny (m. in. odpowiednia aktywność, postawa, ergonomia) mogą zredukować jego występowanie bądź uczynić go mniej traumatyzującym [13]. Ćwiczenia mięśni dna miednicy, jako element specjalnie zaprojektowanego, 12-tygoniowego treningu mogą być pomocne w zapobieganiu LPP w późniejszych okresach ciąży oraz przyczynić się do lepszego funkcjonowania ciężarnej [33]. Dowiedziono, że istnieje związek między dysfunkcją mięśniową a PGP [34]. Stąd hipoteza, że odpowiednie, nakierowane na dysbalans mięśniowy postępowanie, mogłoby zapobiec bądź zmniejszyć dolegliwości związane z PGP. Aktywność fizyczna we wczesnej i średnio-zaawansowanej ciąży związana jest z mniejszym ryzykiem rozwoju PGP oraz, że ryzyko to maleje wraz ze wzrostem liczby godzin w tygodniu poświęconych na ćwiczenia. Aktywność w wodzie związana była z mniejszym odsetkiem PGP niż u kobiet niećwiczących wcale, czego nie zaobserwowano w przypadku jakiejkolwiek innej aktywności fizycznej. Co ciekawe, w przypadku PGP zaobserwowano, że choć aktywność fizyczna dobrze oddziałuje na PGP, to trening oporowy i typu fitness związane są ze zwiększonym ryzykiem wystąpienia PGP [35].

\section{Metody alternatywne}

Akupunktura. Techniki akupunktury uważane są za bezpieczne dla kobiet w ciąży, jednakże terapeuta musi unikać punktów związanych z szyjką macicy i macicą, gdyż wiążą się one z ryzykiem przedwczesnego porodu [37]. Akupunktura efektywniej niż
PGP [34]. Hence the hypothesis that appropriate treatment targeted at muscle disbalance could prevent or reduce PGP-related ailments. Physical activity in early and medium-term pregnancy results in a lower risk of PGP, as this risk decreases with an increase in time devoted to exercise. Physical activity in water resulted in lower PGP risk than in women who did not do physical activity. However, this effect was not observed with any other physical activity. Interestingly, it was noted that while physical activity has a beneficial effect on PGP, resistance exercise and fitness training result in increased risk of PGP [35].

\section{Alternative methods}

Acupuncture. Acupuncture techniques are believed to be safe for pregnant women. Still, therapists need to avoid points related to the cervix and the uterus, as they may prompt premature birth [37]. Acupuncture is more efficient than exercise in relieving evening LPP and disability, and it improves the functioning of the patient. These effects can be achieved if the pain develops in the 26th week of pregnancy. The effects were not observed when pain developed earlier, i.e. in the 20th week of pregnancy [2]. Acupuncture, stabilizing exercises, massage and stretching are equally efficient in reducing pain syndromes that continue post birth [21].

Yoga. It has been proved that yoga, in comparison to posture correction, may lead to pain reduction [20]. However, scientific evidence for yoga effectiveness in LPP treatment is limited, as there have only been a few randomized control studies [21].

Reflexology may be helpful in LPP therapy in reducing pain intensity, pain frequency and disability. It consists in manipulating reflex areas that refer to the pelvis and the back. More reliable randomized control studies are necessary to unquestionably confirm the effectiveness of the method [38].

Osteopathy and chiropractic. It has been proved that patients who received osteopathic treatment along the standard obstetric treatment had less spinal pain than patients who had standard treatment and additional placebo treatment. The procedures included manipulations of soft tissues, myofascial release, movement range improvement techniques, and muscle energy techniques in the cervical, thoracic and lumbar spine, the sacrum and the pelvis, the upper thoracic outlet and the clavicle, the thorax and the diaphragm. There are theoretical premises 
Tab. 1. Porównanie podstawowych zaleceń w przypadku LP i PGP [13]

Tab. 1. A comparison of basic recommendations for LP and PGP [13]

\begin{tabular}{|l|l|}
\hline $\begin{array}{l}\text { Podstawowe postępowanie z LP } \\
\text { Basic recommendations for LP }\end{array}$ & $\begin{array}{l}\text { Podstawowe postępowanie z PGP } \\
\text { Basic recommendations for PGP }\end{array}$ \\
\hline $\begin{array}{l}\text { Codzienne spacery, lub pływanie } \\
\text { Everyday walks or swimming }\end{array}$ & $\begin{array}{l}\text { Ograniczenie wysiłku fizycznego nasilającego bóle } \\
\text { Cutting down on physical effort that intensifies pain }\end{array}$ \\
\hline $\begin{array}{l}\text { Półwałek lędźwiowy korygujący postawę siedząca } \\
\text { Lumbar half roll to correct sitting posture }\end{array}$ & $\begin{array}{l}\text { Odpoczynek podczas epizodów bólowych } \\
\text { Relaxation during pain episodes }\end{array}$ \\
\hline $\begin{array}{l}\text { Podnóżek pod stopy } \\
\text { Footrest }\end{array}$ & $\begin{array}{l}\text { Pas stabilizujący miednicę } \\
\text { Pelvic belt }\end{array}$ \\
\hline $\begin{array}{l}\text { Częste odpoczynki i unikanie długotrwałego siedzenia } \\
\text { Frequent rests and refraining from sitting for a long } \\
\text { time }\end{array}$ & $\begin{array}{l}\text { Siedzenie bez nadmiernego zgięcia w stawach biodrowych i kręgosłupa } \\
\text { Avoiding excessive flexion in hip joints and spine when sitting }\end{array}$ \\
\hline & $\begin{array}{l}\text { Wałek między nogami podczas leżenia } \\
\text { Roll held between legs when lying down }\end{array}$ \\
\cline { 2 - 2 }
\end{tabular}

Tab. 2. Podsumowanie zachowawczych metod leczenia PGP [36]

Tab.2. A summary of non-invasive PGP treatment methods [36]

\begin{tabular}{|l|l|}
\hline $\begin{array}{l}\text { Ogółem } \\
\text { General }\end{array}$ & $\begin{array}{l}\text { Odpoczynek; ograniczenie aktywności wywołujących ból; ćwiczenia stabilizujące kręgosłup } \\
\text { i kompleks lędźwiowo-miedniczy; równowaga pomiędzy odpoczynkiem i aktywnością; leki } \\
\text { przeciwbólowe. } \\
\text { Rest, cutting down on pain-inducing activities, exercises stabilizing the spine and the lumbo- } \\
\text { pelvic area, a good balance of rest and activity, painkillers. }\end{array}$ \\
\hline $\begin{array}{l}\text { Deficyt w mechanizmie ryglowania siłowego } \\
\text { Force closure deficits }\end{array}$ & $\begin{array}{l}\text { Pas stabilizujący miednicę, poniżej kolców biodrowych przednich górnych } \\
\text { z napięciem o sile 50N; ćwiczenia fizyczne skoncentrowane na konkretnym deficycie w kontroli } \\
\text { kompleksu lędźwiowo-miednicznego; rozluźnienie mięśni klatki piersiowej, przepony, mięśnie } \\
\text { dna miednicy. } \\
\text { Pelvic belt below upper front spina iliaca of a tension of 50N, exercises focused on the particu- } \\
\text { lar control deficit in the lumbopelvic area; relaxing muscles of the thorax, diaphragm and pelvic } \\
\text { floor. }\end{array}$ \\
\hline $\begin{array}{l}\text { Nadmierne ryglowanie siłowe } \\
\text { Excessive force closure }\end{array}$ & $\begin{array}{l}\text { Techniki oddechowe, hydroterapia, relaksacja, ćwiczenia aerobowe, ograniczenie globalnych, } \\
\text { intensywnych ćwiczeń stabilizujących, pozycje relaksacyjne. } \\
\text { Breathing techniques, hydrotherapy, relaxation, aerobics, cutting down on intense global stabili- } \\
\text { zing exercise, relaxation positions. }\end{array}$ \\
\hline
\end{tabular}

ćwiczenia znosi wieczorny LPP, niesprawność (ang. disability) oraz poprawia funkcjonowanie. Wyniki te można uzyskać w przypadku, kiedy ból pojawia się w 26 tygodniu ciąży. Tych efektów nie zaobserwowano dla dolegliwości rozpoczynających się wcześniej, w 20 tygodniu [2]. Wskazuje się na taką samą skuteczność akupunktury w zmniejszaniu dolegliwości bólowych utrzymujących się po porodzie, jak ćwiczeń stabilizacyjnych, masażu i stretchingu [21].

Joga. Wykazano, że joga, w porównaniu do korekcji postawy, może prowadzić do zmniejszenia dolegliwości bólowych [20]. Dowody na efektywność jogi w leczeniu LPP są jednak bardzo ograniczone ze względu na znikomą liczbę randomizowanych badań kontrolnych na ten temat [21].

Refleksoterapia może być pomocna w terapii LPP, zmniejszając intensywność i częstotliwość bólu oraz niesprawność. Polega na opracowaniu punktów reflektorycznych odpowiednich dla miednicy i pleców. Jednak by bezsprzecznie potwierdzić jej skuteczność, potrzeba większej liczby rzetelnych, randomizowanych badań kontrolnych [38]. that High Voltage Low Amplitude thrust techniques as well as the fourth ventricle compression techniques may be risky for the pregnant patient and for the foetus or may lead to premature birth. Therefore, the effectiveness of these procedures in LPP treatment has not been studied [39]. There have been reports on positive effects of chiropractic treatment on pain and disability. However, the same effects were achieved with stabilization exercises [40]. Craniosacral therapy is used in LPP treatment, too. Elden et al. noted lower morning intensity of pain and less diminished function when standard therapy was paired with craniosacral therapy, as opposed to using standard treatment only (patient education, stabilizing belt, instructions for doing strengthening and stretching exercises). Still, in this case scientific evidence is not sufficient enough [21].

Kinesiotaping. The method is simple to use and safe and it does not involve pharmacotherapy. It helps in numerous ailments of the locomotor system and also proves helpful in ailments suffered by pregnant women, especially as a supplementary 
Osteopatia i chiropraktyka. Wykazano, że pacjentki, które oprócz standardowej opieki położniczej otrzymały leczenie osteopatyczne w mniejszym stopniu doświadczały dolegliwości bólowych kręgosłupa niż pacjentki objęte standardową opieką i poddane dodatkowej terapii placebo. Do zastosowanych przez nich procedur należały techniki tkanek miękkich, rozluźnianie mięśniowo-powięziowe, techniki nakierowane na poprawę zakresu ruchu oraz techniki energii mięśniowej wykonane w rejonach szyjnego, piersiowego i lędźwiowego odcinka kręgosłupa, kości krzyżowej i miednicy, górnego otworu klatki piersiowej i obojczyków oraz klatki piersiowej i przepony. Istnieją teoretyczne przesłanki, że techniki o wysokiej prędkości i niskiej amplitudzie (ang. HVLA thrust techniques) oraz techniki kompresji komory czwartej mózgu mogą powodować zagrożenie dla ciężarnej i płodu bądź prowadzić do przedwczesnego porodu. W związku z tym, nie badano efektywności tych procedur $\mathrm{w}$ terapii LPP [39]. Doniesiono również o pozytywnym wpływie postępowania chiropraktycznego na odczuwany ból i niesprawność. Takie same efekty uzyskali jednak w przypadku stosowania ćwiczeń stabilizacyjnych [40]. Również terapia kraniosakralna znajduje zastosowanie w leczeniu LPP. W badaniach Elden i wsp. [41] zanotowano mniejszą poranną intensywność bólu i mniejszą utratę funkcji w przypadku połączenia terapii kraniosakralnej ze standardową, w porównaniu do pojedynczo stosowanej standardowej terapii (edukacja pacjenta, pas stabilizujący, instrukcja samodzielnego wykonywania ćwiczeń wzmacniających i rozciągających) Jednak i tu liczba dostępnych dowodów jest wciąż niewystarczająca [21].

Kinesiotaping. Jako prosta w użyciu, bezpieczna i niefarmakologiczna metoda terapii wielu dolegliwości układu ruchu, znajduje również swoje zastosowanie w dolegliwościach okresu ciąży, szczególnie jako metoda uzupełniająca. Kaya i Yosunkaya [42] donieśli o większej skuteczności kinestiotapingu w zmniejszaniu LPP niż grupowych ćwiczeń dla kobiet w ciąży. W badaniach Kaplan i wsp. [43] wśród pacjentek, u których oprócz terapii paracetamolem zastosowane też aplikację kinesiotaping, uzyskano istotnie większą redukcję bólu zarówno w spoczynku jak i podczas aktywności. Reyhan i wsp. [44] w swoim przeglądzie piśmiennictwa konkludują jednak, że brak jest wystarczająco silnych dowodów na jego skuteczność w terapii LPP. method. Kaya and Yosunkaya [42] reported higher effectiveness of kinesiotaping in reducing LPP than of group exercise for pregnant women. Kaplan et al. [43] studied patients whose pain was relieved with paracetamol along with kinesiotaping, and their pain reduction was significantly better both at rest and in activity. In their review of the literature, Reyhan et al. [44] concluded, however, that there is not enough scientific evidence to prove the effectiveness of kinesiotaping in LPP treatment.

\section{Summary}

LPP requires an individualized and complex treatment. There is no single and most effective treatment strategy. A combination of evidence-based methods produces the best treatment outcomes. Healthcare professionals should not refrain from treating pregnant women. Current knowledge gives us a variety of effective tools which help reduce pain and functional limitations with no harm to either a mother or foetus. Appropriate and early interventions will make it possible to reduce the number of patients suffering from this long-term dysfunction. 


\section{Podsumowanie}

LPP wymaga zastosowania zindywidualizowanego, kompleksowego postępowania. Brak jest jednej, najefektywniejszej strategii leczenia - najlepsze wyniki przynosi kombinacja metod, których skuteczność została potwierdzona badaniami. Pracownicy służby zdrowia nie powinni obawiać się pracy z kobietą w ciąży. Dzisiejsza nauka daje wiele efektywnych narzędzi radzenia sobie z tymi dolegliwościami, bez szkody dla matki i dziecka. Odpowiednie i wcześnie wdrożone postępowanie pozwoli ograniczyć liczbę osób cierpiących na długotrwałą dysfunkcję.

\section{Piśmiennictwo/References:}

1. Mens JM, Huis in 't Veld YH, Pool-Goudzwaard A. Severity of signs and symptoms in lumbopelvic pain during pregnancy. Man Ther 2012; 17: 175-9.

2. Pennick V, Liddle SD. Interventions for preventing and treating pelvic and back pain in pregnancy (review). Cochrane Database Syst Rev. 2013 Aug 1;(8):CD001139. doi: 10.1002/14651858.CD001139.pub3.

3. Wu WH, Meijer OG, Uegaki K, Mens JM, van Dieen JH, Wuisman PI, Ostgaard HC. Pregnancy-related pelvic girdle pain (PPP), I: Terminology, clinical presentation and prevalence. Eur Spine J 2004; 13: 575-89.

4. Vermani E, Mittal R, Weeks A. Pelvic girdle pain and low back pain in pregnancy: a review. Pain Pract 2010; 10(1): 60-71.

5. Engeset J, Stuge B, Fegran L. Pelvic girdle pain affects the whole life - a qualitative interview study in Norway on women's experiences with pelvic girdle pain after delivery. BMC Res Notes 2014 [cited 2016 May 9]; 7:686. Available form: http:// bmcresnotes.biomedcentral.com/articles/10.1186/1756-0500-7-686

6. Vleeming A, Albert HB, Ostgaard HC, Stuge B, Sturesson B. European guidelines on the diagnosis and treatment of pelvic girdle pain. Eur Spine J 2008; 17(6): 794-819.

7. Kanakaris NK, Roberts CS, Giannoudis PV. Pregnancy-related pelvic girdle pain: an update. BMC Med 2011 [cited 2015 Jun 14]; 9:15. Available from: http://www.biomedcentral.com/1741-7015/9/15

8. O'Sullivan PB, Beales DJ. Diagnosis and classification of pelvic girdle pain disorders - Part 1: A mechanism based approach within a biopsychosocial framework. Man Ther 2007; 2: 86-97.

9. Kroenke K Bair M, Damush T, Hoke S, Nicholas G, Kempf C, et al. Stepped care for affective disorders and musculoskeletal pain (SCAMP) study design and practical implications of an intervention for comorbid pain and depression. Gen Hosp Psychiatry 2007; 29: 506-17.

10. Van Benten E, Pool J, Mens J, Pool-Goudzwaard A. Recommendations for physical therapists on the treatment of lumbopelvic pain during pregnancy: a systematic review. J Orthop Sports Phys Ther 2014; 7: 464-73.

11. Pelvic, Obstetric and Gynaecological Physiotherapy (POGP) Pregnancy-related pelvic girdle pain: guidance for health professionals. 2015 [cited 2016 Jan 10]. Available from:

12. http://www.csp.org.uk/sites/files/csp/secure/pogp-pgppros_1.pdf

13. Pierce H, Homer CS, Dahlen HG, King J. Pregnancy-related lumbopelvic pain: listening to Australian women. Nurs Res Pract 2012; vol. 2012 [cited 2015 Dec 13]. Available from: http://www.hindawi.com/journals/nrp/2012/387428/

14. Katonis P, Kampouroglou A, Kakavelakis K, Lykoudis S, Makrigiannakis A, Alpantaki K. Pregancy-related low back pain. Hippokratia 2011; 15(3): 205-10.

15. Mens JM, Damen L, Snijders CJ, Stam HJ. The mechanical effect of a pelvic belt in patients with pregnancy-related pelvic pain. Clin Biomech 2006; 21: 122-7.

16. Lile J, Perkis J, Hammer RL, Loubert PV. Diagnostic and management strategies for pregnant women with back pain. JAPA2003; 16: 31-44.

17. Stafne SN, Salvesen KA, Romundstad PR, Stuge B, Morkved S. Does regular exercise during pregnancy influence lumboplvic pain? A randomized controlled trial. Acta Obstet Gynecol Scand 2012; 91: 552-9.

18. Stuge B, Laerum E, Kirkesola G, Vollestad N. The efficacy of a treatment program focusing on specific stabilizing exercises for pelvic girdle pain after pregnancy, a radnomized control trial. Spine 2004a; 29(4): 351-9.

19. Stuge B, Veierod MB, Laerum E, Vollestad N. The efficacy of a treatment program focusing on specific stabilizing exercises for pelvic girdle pain after pregnancy: a two-year follow-up of a randomized clinical trial. Spine 2004b; 29: E197-203. 
20. Kluge J, Hall D, Louw Q, Theron G, Grove D. Specific exercises to treat pregnancy-related low back pain in a South African population. J Gynecol Obstet 2011; 113: 187-91.

21. Martins RF, Pinto e Silva JL. Treatment of pregnancy-related lumbar and pelvic girdle pain by the yoga method: a randomized controlled study. J Altern Complement Med 2014; 20: 24-31.

22. Gutke A, Betten C, Degerskar K, Pousette S, Fagevk Olsen MF. Treatments for pregnancy-related lumbopelvic pain: a systematic review of physiotherapy modalities. Acta Obstet Gynecol Scand 2015; 94: 1156-67.

23. Granath AB, Hellegren MS, Gunnarsson RK. Water aerobics reduces sick leave due to low back pain during pregnancy. J Obstet Gynecol Neonatal Nurs 2006; 35: 465-471.

24. George JW, Skaggs CD, Thompson PA, Nelson DM, Gavard JA, Gross GA. A randomized controlled trial comparing a multimodal intervention and standard obstetrics care for low back and pelvic pain in pregnancy. Am J Obstet Gynecol 2013; 4: 295.e1-295.e7.

25. Nascimiento SL, Surita FG, Cecatti JG. Physical exercise during pregnancy: a systematic review. Curr Opin Obstet Gynecol 2012; 24(6): 387-94.

26. Peterson CD, Haas M, Gregory WT. A pilot randomized controlled trial comparing the efficiacy of exercise, spinal manipulation, and neuroemotional technique for the treatment of pregnancy-related low back pain. Chiropr Man Therap 2012 [cited 2016 Jan 16]; 20:18. Available from: http://www.chiromt.com/content/20/1/18

27. Murphy DR, Hurwitz EL, McGovern EE. Outcome of pregnancy-related lumbopelvic pain treated according to a diagnosis -based decision rule: a prospective observational cohort study. J Manipulativ Physiol Ther 2009; 32: 616-24.

28. Coldron Y, Crothers E. Cook T, Watson T, Notcutt W. ACPWH guidance on the safe use of transcutaneus electrical nerve stimulation (TENS) for musculoskeletal pain during pregnancy. Journal of the Association of Chartered Physiotherapists in Women's Health 2012; 111 (Autumn 2012): 22-26.

29. Keskin EA Onur O, Keskin HL, Gumus II, Kafali H, Turhan N. Transcutaneus electrical nerve stimulation improves low back pain during pregnancy. Gynecol Obstet Invest 2012; 74: 76-83.

30. Arumugam A, Milosavljevic S, Woodley S, Sole G. Effects of external pelvic compression on form closure, force closure, and neuromotor control of the lumbopelvic spine: A systematic review. Man Ther 2012; 17: 275-84.

31. Kordi R, Abolhasani M, Rostami M, Hantoushzadeh S, Mansournia MA, Vasheghani-Farahani F. Comparison between the effect of lumbopelvic belt and home based pelvic stabilizing exercise on pregnant women with pelvic girdle pain: a randomized controlled trial. J Back Musculoskeletal Rehabil 2013; 26: 133-9.

32. Flack NA, Hay-Smith EJ, Stringer MD, Gray AR, Woodley SJ. Adherence, tolerance and effectiveness of two different pelvic support belts as a treatment for pregnancy-related symphyseal pain - a pilot randomized trial. BMC Pregnancy Childbirth 2015 [cited 2016 Jan 10]; 15:36 Available from: http://www.ncbi.nlm.nih.gov/pmc/articles/PMC4339641/pdf/12884_2015_Article_468.pdf

33. Bastiaenen CH, de Bie RA, Essed GG. Pregnancy-related pelvic girdle pain. Acta Obstet Gynecol Scand 2007; 86: 1277-8.

34. Morkved S, Salvesen KA, Schei B, Lydersen S, Bo K. Does group training during pregnancy prevent lumbopelvic pain? A randomized clinical trial. Acta Obstet Gynecol Scand 2007; 86(3): 276-82.

35. Gutke A, Ostgaard HC, Oberg B. Association between muscle function and low back pain in relation to pregnancy. J Reh Med 2008; 40: 304-11.

36. Andersen LK, Backhausen M, Hegaard HK, Juhl M. Physical exercise and pelvic girdle pain in pregnancy: a nested case-control study within the Danish National Birth Cohort. Sex Reprod Heathc 2015; 6: 198-203.

37. Verstraete EH, Vanderstraeten G, Parewijck W. Pelvic girdle pain during or after pregnancy: a review of recent evidence and a clinical care path proposal. Facts Views Vis ObGyn 2013; 5(1): 33-43.

38. Moffat M, Flynn M. Safety of acupuncture in pregnancy. JAACP 2013; Spring: 41-50.

39. Close C, Sinclair M, McCullough JM, Liddle D, Hughes C. A pilot randomised controlled trial (RCT) investigating the effectiveness of reflexology for managing pregnancy low back and/or pelvic pain. Complement Ther Clin Pract 2015: published online 2015 May 12 [cited 2016 Jan 10]. Available form: http://dx.doi.org/10.1016/j.ctcp.2015.05.002

40. Licciardone JC, Aryal S. Prevention of progressive back-specific dysfunction during pregnancy: an assessment of osteopathic manual treatment based on Cochrane Back Review Group Criteria. Journal Am Osteopath Assoc 2013; 10: 728-36.

41. Peterson CD, Haas M, Gregory WT. A pilot randomized controlled trial comparing the efficiacy of exercise, spinal manipulation, and neuroemotional technique for the treatment of pregnancy-related low back pain. Chiropr Man Therap 2012; 20:18. [cited 2016 Jan 16]. Available from: http://www.chiromt.com/content/20/1/18

42. Elden H, Ostgaard HC, Glantz A, Marciniak P, Linner AC, Olsen MF. Effects of craniosacral therapy as adjunct to standard treatment for pelvic girdle pain in pregnant women: a multicenter, single blind, randomized controlled trial. Acta Obstet Gynecol Scand 2013; 92: 775-82.

43. Kaya E., Yosunkaya N. The effect of kinesiotaping on low back pain during pregnancy. Turk Fiz Tip Rehab Derg 2013; 59; SUPPL. 1 (248).

44. Kaplan S., Alpayci M., Karaman E., Cetin O., Ozkan Y, Server I., Sah V., Sahin HG. Short-term effects of Kinesio Taping in women with pregnancy-related low back pain: a randomized controlled clinical trial. Med Sci Monit 2016; 22; 1297-1301.

45. Reyhan AC., Dereli EE., Colak TH. Low back pain during pregnancy and Kinesio tape application. J Back Musculoskelet Rehabil 2016: Published online 2016 Dec 23 [cited 2017 March 28]. Available from: http://dx.doi.org/10.3233/BMR-160584. 